\section{The Pathogenesis of Poliomyelitis}

By Prof. Harold K. Faber. (American Lecture Series-No. 257. A Monograph in American Lectures on Pediatrics.) Pp. xvi +157 . (Springfield, IIl. : Charles C. Thomas; Oxford: Blackwell Scientific Publications, 1955.) 36s.

$\mathrm{H}^{\mathrm{XACTLY}}$ where the virus of poliomyelitis first 1 invades the body has long been the subject of speculation, as also has the problem of its subsequent dissemination. These topics have for many years afforded a fruitful field for collaboration between anatomists and pathologists. The concept of the axonal transmission of poliomyelitis, first clearly formulated by Fairbrother and Hurst in 1930, soon met with the approval of Prof. H. K. Faber, who has staunchly advocated it ever since. The present work is a re-statement of his views, in the face of evidence which in recent yoars has appeared to cast doubt upon them.

His main thesis is that virus first enters the mucosa of the mouth and pharynx, and then spreads centripetally along the axons of sensory nerves to reach their ganglia, in which $21-48 \mathrm{hr}$. after exposure it begins to multiply. Two to three days later, the virus then reverses its direction and passes centrifugally to be excreted into the oropharynx, whence axonal ro-invasion with further centripetal spread of virus may occur, while in addition varying amounts of virus are swallowed. Virus particles in the intestine, he suggests, may be absorbed in exactly the same way as undigested protein; and only thus do they reach the liver, or the intestinal and mesenteric lymphoid tissue, and the blood stream. Virus obtains accoss to the central nervous system either from the blood stream, or from the peripheral ganglia if thoy are severely infected.

Prof. Faber considers that the tissue culture experiments of Enders and his colleagues have no relevance to his argument. For though they showed that virus in tissue culture could grow outside the nervous system, and possibly in the complete absence of nervous tissue, Faber maintains that conditions in vitro and in vivo are fundamentally different. It is all the more surprising that he does not mention the experiments of German and Trask, which are esppcially pertinent in this connexion; nor does he seriously consider the possibility of cellular transport of virus mediated through the lymphoid tissues.

\section{J. M. YoFFEY}

\section{A Manual of the Dragonflies of North America (Anisoptera)}

Including the Greater Antilles and the Provinces of the Mexican Border. By Prof. James G. Needham and Prof. Minter J. Westfall, Jr. Pp. xii +615 . (Berkeley and Los Angeles: University of California Press ; London: Cambridge University Press, 1955.) $94 s$. net.

MORE than twenty-five years after the pub. 1 lication of his earlier book on the dragonflies of North America, Prof. J. C. Neodham, in collaboration with Prof. M. J. Westfall, has now written the first part of a new and enlarged work, dealing with the sub-order Anisoptera. The need for it is evident from the fact that, since his first work, the list of species in the North American Anisoptera has grown from 245 to 332 .

Most of the book naturally deals with the taxonomy of the group, but there are chapters devoted to the structure and life-history of the Anisoptera, to the methods employed for collecting adults and nymphs and for studying thom in the field and laboratory. In the systematic part, keys and tables are given for the identification of families, genera and species (both adults and nymphs, where known), and under each species are given not only a description but also the principal bibliographic references, distribution and the period of flight of the adults.

The whole book is lavishly illustrated with line and half-tone illustrations of venation, genitalia and nymphs, all of a high level of excellence. Most of the photographs were taken by Prof. Westfall and were produced by the methods outlined in a joint paper with A. L. Smith (J. Biol. Phot. Ass., 19, No. 2, 74 ; 1951). The manual will certainly be of great value, not only to American students of Odonata but also to others interested in these flies, and the publication of the companion volume on the Zygoptera, which is in preparation, is eagerly awaited.

\section{E. Kimmins}

\section{Optical Instrumentation}

Fdited by Prof. George S. Monk and W. H. McCorkle. (National Nuclear Fnergy Series : Manhattan Project Technical Section. Division 4-Plutonium Project Record : Vol. 8.) Pp. xxv + 262. (London: McGrawHill Publishing Company, Ltd., 1954.) $30 s$.

HIS book is not of sufficient quality to justify the claim that it may be used as a text-book. The editorial advisory board finds it necessary to warn the reader to expect discrepancies and duplication on the plea that promptness of publication seerned more important: this is scarcely a recommendation for a reference book. Even so, it is a little too much to find that a smoke tester mentioned on p. 49 as being developed for particles $0.04 \mathrm{~cm}$. in diameter is actually intended for particles $\frac{1}{4} \mu$ diameter according to paper 5.2 (not paper 5.3 as given by the reference). This paper makes the illuminating statement that cigar.smoke is the limit of precision of the method--the reader being left to draw his own conclusions. Techniques are mainly experimental and restricted both by time and to available lenses. It is thus not surprising to read on p. 15 "the best definition was not always obtained".

Theory is but briefly considered. In section 1.2, on brightness of images, it is stated that if the size of the entrance pupil is sufficiently larger than the exit pupil to compensate for light losses in the system, the intensity of a point object will be increased. The influence of the diameter of the pupil of the eye is not discussed. The book is not without interest, however: the problems encountered are outlined; the replacement of optical glass, darkened by high-energy radiation, by plastics is mentioned; and some valuable work on evaporation in vacuum is recorded.

G. W. HAMSTEAD

\section{The Ocean Floor}

By Hans Pettersson. (Silliman Memorial Lectures.) Pp. xv + 181. (New Haven, Conn. : Yale University Press; London: Oxford University Press, 1954.) 3 doilars; $24 s$. net.

LTHOUGH the sea-floor covers approximately A two-thirds of the Earth's surface, our knowledge of its morphology, structure and composition is meagre. For many years after the Challenger Expedition $(1872-76)$ there was little progress, largely due to the lack of improved apparatus for investigating the deep-sea floor. Although the Challenger took cores $2 \mathrm{ft}$. in length, there was little improvement until Dr. B. Kullenberg, during the Second World 